\title{
PERTUMBUHAN DAN HASIL GALUR-GALUR F 4 PADI RAWA PADA RAWA LEBAK
}

\author{
Sumardi $^{1 *}$, M. Chozin ${ }^{1}$, Hermansyah ${ }^{1}$ \\ ${ }^{1}$ Program Studi Agroekoteknologi, Fakultas Pertanian Universitas Bengkulu \\ *Corresponding Author : sumardi@unib.ac.id
}

\begin{abstract}
[GROWTH AND YIELD OF $\mathrm{F}_{4}$ SWAMP RICE LINES ON LINE SWAMP]. Growth and yield of swamp rice are depending on the plant ability to adapt in swampy agro-ecosystem which characterized by several limiting factors. This study was addressed to evaluate the growth and yield characteristics of six lines of swamp rice bred for the development of high-yielding rice varieties best suited for swamp land production. Evaluation was conducted in a pot experiment using UBPR2, UBPR3,UBPR6, UBPR7, UBPR9, and UBPR10 as planting materials. These lines were the $\mathrm{F}_{4}$ generation derived from crosses involving local Bengkulu swamp rice varieties. Observations were made on 13 plant characteristics, dry matter accumulation, leaf area ratio, specific leaf weight, net assimilation rate, plant height, productive tiller number, heading date, maturity date, panicle length, grain number per panicle, percent of filled grain, and plant yield (the grain weight per clump). The collected data were subjected to analysis of variance and least significant difference test at 5\% level. Results indicated that all lines physiologically exhibited similar growth patterns, excepting the capability of accumulating dry matter at 40 dap. In this case, UBPR6 produced the highest dry matter accumulation (24.34 g). Based on the morphological performances, significant variations among the lines were observed on most of the observed characteristics, except on productive tiller number and panicle length UBPR10 was the line produced the tallest plant stature $(160.72 \mathrm{~cm})$, UBPR2 was the earliest flowering and maturing line $(76,33$ and 111 dap), whereas UBPR6 was the line produced the highest grain number/panicle $(212,2)$, percent of filled grain $(95 \%)$, and plant yield ( $82.50 \mathrm{~g} / \mathrm{clump})$.
\end{abstract}

Keyword: $F_{4}$ generation swamp rice lines, growth, inland swamp , yield/clump

\begin{abstract}
ABSTRAK
Pertumbuhan dan hasil padi rawa sangat bergantung kemampuan tanaman dalam beradaptasi pada agroekosistem rawa yang umumnya dicirikan dengan berbagai faktor pembatas. Penelitian ini bertujuan untuk mengevaluasi karakteristik pertumbuhan dan hasil dari enam galur padi yang dikembangkan untuk menghasilkan varietas berdaya hasil tinggi yang sesuai untuk budidaya lahan rawa. Evaluasi dilaksanakan dalam bentuk percobaan pot dengan menggunakan bahan tanam dari galur UBPR2, UBPR3, UBPR6, UBPR7, UBPR9 dan UBPR10.Galur-galur tersebut merupakan generasi $\mathrm{F}_{4}$ dari persilangan dengan sumber gen dari padi lokal Bengkulu. Pengamatan dilakukan terhadap 13 sifat tanaman yang meliputi akumulasi bahan kering, rasio luas daun, bobot daun khusus, laju asimilasi bersih, laju pertumbuhan relatif, tinggi tanaman, jumlah anakan produktif, umur berbunga, umur panen, panjang malai, jumlah gabah per malai, persentase gabah bernas, dan hasil tanaman (bobot gabah per rumpun). Data yang terkumpul dianalisis secara statistik dengan analisis keragaman dan uji bedanyata terkecil pada taraf 5\%. Hasil analisis menunjukkan bahwa secara fisiologis galur-galur yang dievaluasi menunjukkan pola pertumbuhan yang serupa, kecuali kemampuan tanaman dalam mengakumulasi bahan kering pada umur 43 hst. Padi galur UBPR6 memiliki kemampuan mengakumulasi bahan kering tertinggi $(24,34 \mathrm{~g})$. Berdasarkan penampilan morfologisnya, keragaman yang nyata dijumpai pada hampir seluruh sifat yang diamati, kecuali jumlah anakan produktif dan panjang malai. UBPR10 merupakan galur yang memiliki postur tanaman tertinggi $(160,72 \mathrm{~cm})$, UBPR2 merupakan galur dengan umur berbunga dan umur panen paling genjah (76,33 dan111 hst), sedangkan UBPR6 jumlah gabah/malai tertinggi $(212,2)$, persentase gabah bernas tertinggi( $95 \%)$, dan hasil tanaman tertinggi $(82,50 \mathrm{~g} /$ rumpun).
\end{abstract}

Kata kunci: galur, generasi F4, hasil per rumpun, pertumbuhan, rawa lebak 


\section{PENDAHULUAN}

Permasalahan ketahanan pangan nasional khususnya beras saat ini sudah menjadi permasalahan yang serius, meskipun berbagai upaya telah dilakukan pemerintah untuk meningkatkan produksi pangan, namun belum memberikan hasil yang nyata. Hal ini dapat dilihat dari data pertumbuhan produksi gabah nasional dari tahun ke tahun masih relatif stagnan, yakni selama periode 2010-2014, berturutturt 13,$2 ; 13,2 ; 13,4 ; 13,8$ dan 13,7 juta ton (BPS, 2015).

Selama ini produksi beras masih terfokus dari lahan sawah optimal untuk tanaman padi, baik sawah tadah hujan maupun irigasi. Permasalahannya sekarang ketersediaan lahan optimal tersebut cenderung berkurang, meskipun program pecetakan sawah baru ada dalam setiap tahun, namun belum mampu melampaui lahan sawah tanaman pangan yang beralih fungsi. Potensi sumberdaya alam yang selama ini belum menjadi pusat perhatian sebagai sentra produksi tanaman pangan khususnya padi, antara lain adalah lahan rawa. Lahan rawa ketersediannya masih memungkinkan untuk dikelola sebagai sentra produksi pangan yang produktif khususnya tanaman padi yang memiliki kemampuan beradaptasi baik dengan ekosistem rawa (Alihamsyah \& Ar-Riza, 2004).

Ekosistem rawa memiliki karakteristik yang spesifik, berbeda dengan lahan sawah mineral. Beberapa sifat fisik, kimia dan biologi pada lahan rawa seringkali menjadi faktor pembatas dalam budidaya padi pada ekosistem tersebut diantaranya masalah tata air yang sulit diprediksi, sehingga menyulitkan untuk menentukan waktu tanam (Suwignyo et al., 2008).

Suriadikarta \& Sutriadi (2007), mengemukakan bahwa rawa lebak dicirikan selalu tergenang di musim hujan dan kering di musim kemarau. Sesuai dengan konsep GAP (Good Agricultural Practices), pemanfaatan sumberdaya alam untuk kepentingan manusia diupayakan seminimal mungkin menimbulkan efek negatif terhadap lingkungan semula. Ekosistem rawa yang dapat dimanfaatkan sebagai salah satu sentra produksi pertanian yang produktif dengan tidak merubah karakteristik rawa tersebut, sehingga dapat dimanfaatkan secara berkelanjutan (Sagiman, 2007).

Merakit varietas tanaman padi yang berdaya hasil tinggi dan beradaptasi baik pada ekosistem rawa dengan berbagai faktor pembatas pertumbuhan dan perkembangan tanaman padi, merupakan dasar untuk memanfaatkan ekosistem rawa menjadi salah satu sentra produksi padi (Chozin et al., 2016: Chozin et al., 2017)). Penelitian ini bertujuan untuk mengevaluasi karakteristik pertumbuhan dan hasil dari enam galur padi yang dikembangkan untuk menghasilkan varietas berdaya hasil tinggi yang sesuai untuk budidaya lahan rawa.

\section{METODE PENELITIAN}

Penelitian dilaksanakan di Rumah Jaring Fakultas Pertanian Universitas Bengkulu, mulai Maret-Juli 2017. Percobaan dilakukan menggunakan pot (ember plastik) dengan volume $22 \mathrm{~L}$. Media tanam yang digunakan diambil dari lahan rawa lebak dangkal. Galur F4 yang dievaluasi meliputi UBPR2, UBPR3, UBPR6, UBPR7, UBPR9 dan UBPR10. Masingmasing galur merupakan hasil seleksi pedigree dari persilangan padi rawa lokal Bengkulu, UBPR2 Batubara x Harum Curup, UBPR3 Tigo-tigo x Harum Curup, UBPR6 Tigo-tigo x Sidenuk, UBPR7 Harum Curum x Sidenuk, UBPR9 Lubuk Durian x Hanafi Putih dan UBPR10 Tigo-tigo x Bestari.

Media tanam yang diambil dari lahan rawa lebak dangkal ditiriskan hingga kapasitas lapang dan diisikan sebanyak $10 \mathrm{~kg}$ ke dalam pot. Bibit ditanam secara tunggal pada tiap pot dilakukan ketika semaian dari masing-masing galur telah berumur 15 hari setelah benih ditabur pada media pembibitan. Penelitian ini dilaksanakan dengan menggunakan rancangan acak lengkap dengan tiga ulangan. Urea $(1,538 \mathrm{~g} /$ pot setara dengan $200 \mathrm{~kg} / \mathrm{ha}), \mathrm{SP}-36$ $(1,538 \mathrm{~g} /$ pot setara dengan $100 \mathrm{~kg} / \mathrm{ha})$ dan $\mathrm{KCl}$ $(0,57 \mathrm{~g} /$ pot setara dengan $75 \mathrm{~kg} / \mathrm{ha})$ diberikan pada tiap pot sehari sebelum tanam sebagai pupuk dasar. Khusus pupuk Urea diberikan dua kali masing-masing $0,76 \mathrm{~g} /$ pot sehari sebelum tanam, sisanya diberikan ketika tanaman memasuki fase priomordia (56 hst). Air dalam tiap pot dipertahankan $10 \mathrm{~cm}$ di atas permukaan media tanam hingga hingga panen (mengikuti pola air rawa di lapangan). Panen tanaman dilaksanakan ketika kriteria panen telah dicapai dengan ciri-ciri daun bendera telah mulai menguning dan sebagian daun dibawahnya telah mati, serta $80 \%$ atau lebih gabah telah matang penuh (IRRI, 1980).

Pengamatan dilakukan terhadap 13 sifat tanaman yang meliputi akumulasi bahan kering, rasio luas daun, bobot daun khusus, laju asimilasi bersih, laju pertumbuhan relatif, tinggi tanaman, jumlah anakan produktif, umur berbunga, umur panen, panjang malai, jumlah gabah/malai, persentase gabah bernas, dan hasil tanaman (bobot gabah/rumpun). Data yang terkumpul dianalisis secara statistik dengan analisis keragaman dan uji beda nyata terkecil pada taraf 5\% (Gomez \& Gomez, 1984).

\section{HASIL DAN PEMBAHASAN}

Pertumbuhan dapat dilihat berdasarkan perubahan yang tampak, dapat diukur, dan memerlukan alat pengukuran yang tepat dan akurat yang dapat dibaca secara kuantitatif. Analisis pertumbuhan merupakan suatu cara untuk mengikuti dinamika fotosintesis oleh daun yang diukur dengan menghitung akumulasi bahan kering. 
Hasil analisis keragaman menunjukkan bahwa galur-galur yang dievaluasi pada fase pertumbuhan vegetatif menunjukkan pola pertumbuhan yang serupa, namun berbeda sifat fisiologisnya, tampak pada kemampuan tanaman dalam mengakumulasi bahan kering pada umur 43 hst. Galur UBPR6 memiliki kemampuan mengakumulasi bahan kering tertinggi $(24,34 \mathrm{~g})$ (Tabel 1).

Tabel 1. Akumulasi bahan kering ( $g$ ) enam galur padi rawa

\begin{tabular}{lcccccc}
\hline Galur & 15 hst & 22 hst & 29 hst & 36 hst & 43 hst & 50 hst \\
\hline UBPR2 & 0,27 & 0,97 & 6,28 & 10,83 & $16,65 \mathbf{b}$ & 18,22 \\
UBPR3 & 0,22 & 1,11 & 4,96 & 6,55 & $18.03 \mathbf{b}$ & 19,96 \\
UBPR6 & 0,2 & 0,96 & 4,65 & 11,14 & $23,34 \mathbf{a}$ & 24,74 \\
UBPR7 & 0,34 & 1,48 & 5,79 & 10,25 & $15,56 \mathbf{b}$ & 22,22 \\
UBPR9 & 0,21 & 0,9 & 5,83 & 10,13 & $17,92 \mathbf{b}$ & 22,17 \\
UBPR10 & 0,18 & 1,32 & 5,323 & 10,54 & $14,21 \mathbf{b}$ & 20,96 \\
\hline LSD & $\mathbf{0 , 1 8}$ & $\mathbf{0 , 7 1}$ & $\mathbf{2 , 8 4}$ & $\mathbf{5 , 4 4}$ & $\mathbf{4 , 1 2}$ & $\mathbf{6 , 9 2}$ \\
\hline $\mathbf{0 , 0 5}$ & & & & & & \\
\hline
\end{tabular}

Akumulasi bahan kering mencerminkan kemampuan tanaman dalam mengikat energi dari cahaya matahari melalui proses fotosintesis, serta interaksinya dengan faktor-faktor lingkungan lainnya. Distribusi akumulasi bahan kering pada bagian-bagian tanaman seperti akar, batang, daun dan bagian generatif, dapat mencerminkan produktivitas tanaman

Selain akumulasi bahan kering variabel pertumbuhan yang dapat menilai kualitas pertumbuhan tanaman antara lain Rasio Luas Daun (Yoshida, 1981). Rasio luas daun menggambarkan antara luas lamina daun atau jaringan yang melaksanakan fotosintesis dengan jaringan tanaman total yang melaksanakan respirasi atau biomasa total tanaman. Rasio luas daun secara umumnya berkorelasi positif dengan laju pertumbuhan relatif (Gardner et al., 2008). Pola perkembangan rasio luas daun pada awal pertumbuhan beragam, namun dengan semakin bertambah umur membentuk pola yang hampir sama (Gambar 1). Jumlah helaian daun tanaman padi pada fase-fase awal pertumbuhannya masih sedikit, belum terjadi saling menaungi, sehingga hampir semua helaian daun yang terbentuk berperan sebagai source atau melakukan aktivitas fotosintesis. Sebaliknya bagian tanaman padi yang melakukan respirasi pada fase-fase awal pertumbuhan juga belum besar, sehingga tampak nilai rasio luas daun pada fase awal pertumbuhan relatif tinggi dibandingkan dengan periode waktu selanjutnya, tertama tampak jelas pada Galur UBPR-6. Perkembangan selanjutnya jumlah helaian daun bertambah, namun posisi antara satu daun dengan daun lainnya berada pada garis lurus, sehingga terjadi saling menutupi penetrasi cahaya matahari sampai ke lamina daun, sementara bagian tanaman yang melaksanakan respirasi semakin besar. Pola ini tampak pada semua galur tanaman yang diuji dan klimaknya pada saat tanaman berumur 50 hst yakni pada saat tanaman memasuki fase primordia (Gambar
1). Meskipun secara statistik dari enam galur padi yang diuji pola perubahan rasio luas daun tersebut hingga tanaman berumur 50 hst menunjukkan perbedaan yang tidak nyata

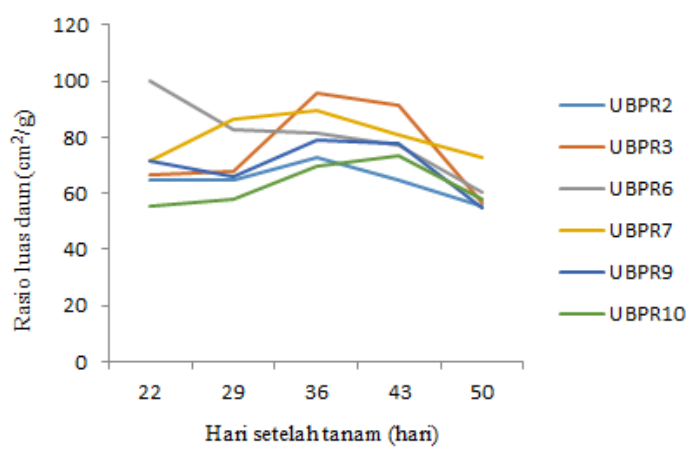

Gambar 1. Rasio luas daun enam galur padi rawa $\left(\mathrm{cm}^{2} / \mathrm{g}\right)$

Pertumbuhan lamina daun secara umum sama dengan pertumbuhan organ tanaman lainnya, namun pasti terdapat perbedaan laju pertumbuhan antara organ tanaman yang satu dengan lainnya. Pertumbuhan lamina daun secara fisik yang dapat dilihat adalah pertambahan luas lamina daun ketebalan daun. Perbedaan karakter pertumbuhan lamina daun tersebut di samping merupakan faktor genetik, juga faktorn lingkungan yang memiliki andil. Daun yang mengalami kekurangan cahaya karena naungan cenderung tumbuh melebar namun tipis, sebaliknya daun yang mendapatkan cahaya matahari penuh, tumbuh proporsional antara lebar dan tebalnya.

Tabel 2. Rata-rata rasio luas daun enam galur padi rawa

\begin{tabular}{lccccc}
\hline Galur & $22 \mathrm{hst}$ & $29 \mathrm{hst}$ & $36 \mathrm{hst}$ & $43 \mathrm{hst}$ & $50 \mathrm{hst}$ \\
\hline UBPR2 & 64,47 & 64,58 & 72,63 & 64,64 & 55,74 \\
UBPR3 & 66,59 & 67,6 & 95,67 & 91,33 & 56,43 \\
UBPR6 & 100,34 & 82,57 & 81,79 & 77,41 & 60,12 \\
UBPR7 & 71,33 & 86,16 & 89,82 & 80,57 & 72,82 \\
UBPR9 & 71,65 & 66,06 & 79 & 78,05 & 54,56 \\
UBPR10 & 55,45 & 58,07 & 69,43 & 73,71 & 57,92 \\
\hline LSD 0,05 & $\mathbf{4 3 , 9 8}$ & $\mathbf{2 2 , 6 6}$ & $\mathbf{4 5 , 6}$ & $\mathbf{3 9 , 0 4}$ & $\mathbf{1 3 , 4 7}$ \\
\hline
\end{tabular}

Perbedaan galur-galur padi yang diuji ada yang memiliki karakter yang berbeda dalam pertumbuhan dan perkembangan daun, sehingga pada fase-fase awal pertumbuhan tampak bervariasi. Setelah tanaman berumur 36 hst cenderung memiliki bobot daun khusus yang relatif seragam menurun hingga pengamatan pada umur tanaman 43 hst. Selanjutnya bobot daun khusus dari galur-galur yang diuji semuanya kembali meningkat hingga tanaman berumur $50 \mathrm{hst}$. 
Pola perkembangan bobot daun khusus pada awal pertumbuhan beragam, namun dengan semakin bertambah umur membentuk pola yang hampir sama mulai tampak pada umur 36 hst hingga 43 hst (Gambar 2). Berdasarkan analisis statistik selama periode vegetatif, dengan melakukan pengamatan selama lima minggu keenam galur memiliki bobot daun khusus yang serupa, namun secara fisik di lapangan terlihat perbedaannya (Tabel 3). Bobot daun khusus (specific leaf weight) menggambarkan ketebalan daun suatu tanaman. Bobot daun khusus yang rendah artinya tanaman toleran terhadap cahaya rendah dibandingkan dengan tanaman yang memiliki bobot daun khusus tinggi. Bobot daun khusus yang rendah biasanya memiliki ketebalan daun yang tipis, namun memiliki ukuran daun yang lebih lebar. Daun yang lebar dan tipis memungkinkan penangkapan cahaya lebih banyak dan diteruskan ke bagian daun yang lebih bawah dengan cepat sehingga kegiatan fotosintesis berlangsung maksimal.

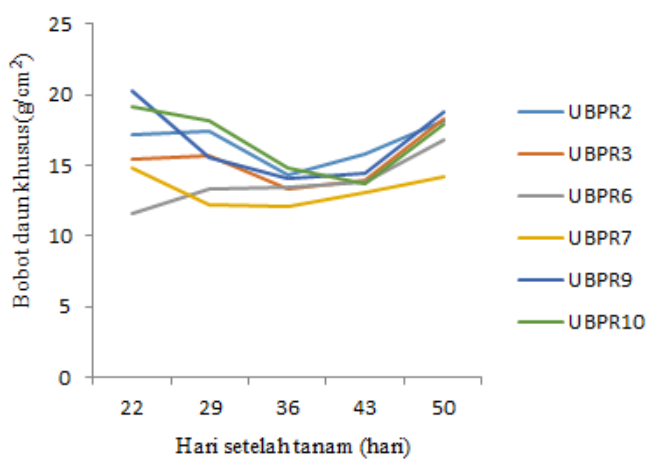

Gambar 2. Bobot daun khusus enam galur padi rawa $\left(\mathrm{g} / \mathrm{cm}^{2}\right)$

Tabel 3. Rata-rata bobot daun khusus enam galur padi rawa $\left(\mathrm{g} / \mathrm{cm}^{2}\right)$

\begin{tabular}{lccccc}
\hline Galur & 22 hst & 29 hst & 36 hst & 43 hst & 50 hst \\
\hline UBPR2 & 17,19 & 17,2 & 14,34 & 15,82 & 18,15 \\
UBPR3 & 15,43 & 15,66 & 13,34 & 14 & 18,26 \\
UBPR6 & 11,6 & 13,31 & 13,46 & 13,8 & 16,76 \\
UBPR7 & 14,85 & 12,25 & 12,07 & 13,05 & 14,24 \\
UBPR9 & 20,29 & 15,54 & 14,05 & 14,47 & 18,74 \\
UBPR10 & 19,1 & 18,2 & 14,76 & 13,72 & 17,89 \\
\hline LSD $\mathbf{0 , 0 5}$ & $\mathbf{9 , 5 6}$ & $\mathbf{6 , 3 5}$ & $\mathbf{5 , 2 5}$ & $\mathbf{3 , 9 7}$ & $\mathbf{4 , 2 6}$ \\
\hline
\end{tabular}

Laju asimilasi bersih didefinisikan sebagai kenaikan dalam berat kering tanaman persatuan waktu per satuan luas daun. Laju asimilasi bersih dapat dipandang sebagai suatu ukuran efisiensi dari setiap satuan luas daun melakukan fotosintesis untuk mengakumulasikan bahan kering tanaman. Laju asimilasi bersih dipengaruhi oleh luas daun yang berfungsi menangkap energi radiasi surya dan intensitas cahaya serta suhu. Suhu berpengaruh langsung terhadap aktivitas fotosintesis dan proses respirasi, yang substratnya adalah bahan kering yang diakumulasikan selama proses fotosintesis.

Dari enam galur yang diuji pola laju asimilasi bersih secara umum terus menurun sejak umur tanaman 29, hingga mendekati 0 (nol) pada umur tanaman 50 hst (Gambar 3). Secara statistik laju asimilasi bersih dari ke-enam galur yang diuji pada setiap titik pengamatan tidak menunjukkan perbedaan yang nyata. Laju asimilasi bersih tertinggi terjadi pada saat tanaman berumur 22 hst. Hal ini terjadi hampir pada seluruh galur yang diuji (Tabel 4).

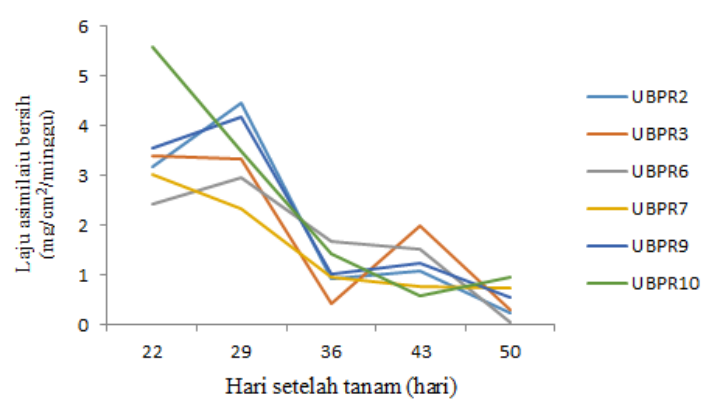

Gambar 3. Laju asimilasi bersih enam galur padi rawa $\left(\mathrm{mg} / \mathrm{cm}^{2} / \mathrm{minggu}\right)$

Tabel 4. Rata-rata laju asimilasi bersih $\left(\mathrm{mg} / \mathrm{cm}^{2} /\right.$ minggu) enam galur padi rawa

\begin{tabular}{lccccc}
\hline Galur & 22 hst & 29 hst & 36 hst & 43 hst & 50 hst \\
\hline UBPR2 & 3,17 & 4,45 & 0,93 & 1,08 & 0,24 \\
UBPR3 & 3,39 & 3,34 & 0,43 & 1,97 & 0,28 \\
UBPR6 & 2,42 & 2,95 & 1,66 & 1,52 & 0,03 \\
UBPR7 & 3.03 & 2,33 & 0,95 & 0,75 & 0,73 \\
UBPR9 & 3,55 & 4,18 & 1,02 & 1,22 & 0,54 \\
UBPR10 & 5,59 & 3,48 & 1,43 & 0,58 & 0,94 \\
\hline LSD 0,05 & $\mathbf{2 , 2 1}$ & $\mathbf{2 , 4 2}$ & $\mathbf{1 , 2 4}$ & $\mathbf{1 , 2 2}$ & $\mathbf{0 , 7 7}$ \\
\hline
\end{tabular}

Laju pertumbuhan relatif merupakan peningkatan bobot kering tanaman dalam suatu interval waktu tertentu. Hasil analis ragam menunjukkan bahwa keenam galur yang diuji memiliki rata-rata laju pertumbuhan relatif berbeda tidak nyata selama peride pengamatan 15-22 hst, 22-29 hst, 29-36 hst, 36-43 hst dan 43-50 hst. Laju pertumbuhan relatif enam galur yang diuji memiliki pola yang mirif, periode umur 22-29 hst merupakan laju pertumbuhan relatif tertinggi, selanjutnya menurun hingga mendekati titik nol (Gambar 4). Hasil rata-rata dari keenam galur yang diuji, UBPR6 memiliki laju pertumbuhan relatif terendah pada saat tanaman memasuki fase primordia, yakni pada saat tenaman berumur $50 \mathrm{hst}$ (Tabel 5). 


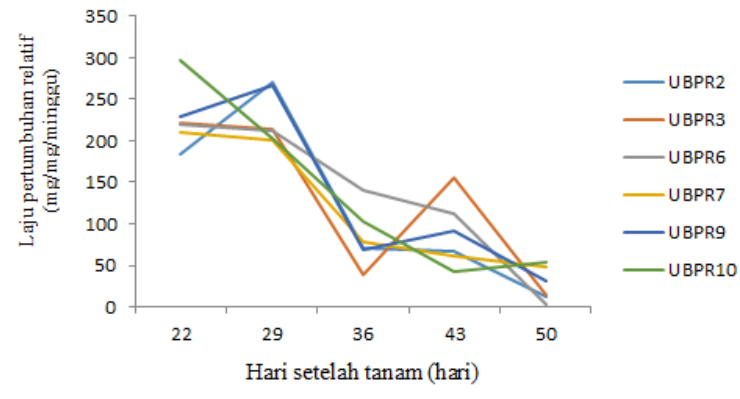

Gambar 4. Laju pertumbuhan relatif enam galur padi rawa $(\mathrm{mg} / \mathrm{mg} / \mathrm{minggu})$

Tabel 5. Rata-rata laju pertumbuhan relatif enam galur padi rawa $(\mathrm{mg} / \mathrm{mg} / \mathrm{minggu})$

\begin{tabular}{lccccc}
\hline Galur & 22 hst & 29 hst & 36 hst & 43 hst & 50 hst \\
\hline UBPR2 & 183,74 & 269,6 & 70,46 & 67,96 & 13,21 \\
UBPR3 & 222,03 & 214,12 & 37,99 & 155,06 & 13,37 \\
UBPR6 & 220,29 & 212,14 & 140,46 & 111,77 & 2,32 \\
UBPR7 & 210,63 & 200,48 & 79,12 & 62,02 & 48,2 \\
UBPR9 & 229,04 & 266,6 & 68,48 & 91,01 & 30,85 \\
UBPR10 & 296,51 & 203,12 & 102,34 & 42,69 & 53,44 \\
\hline LSD 0,05 & $\mathbf{1 0 6 , 4 7}$ & $\mathbf{1 1 9 , 4 1}$ & $\mathbf{9 9 , 4 5}$ & $\mathbf{1 0 9 , 1 3}$ & $\mathbf{4 3 , 9}$ \\
\hline
\end{tabular}

Pertumbuhan didefinisikan sebagai adanya peningkatan jumlah serta peningkatan ukuran sel sehingga terjadi perubahan keragaan pada tanaman dan bersifat tidak bisa kembali (irreversible). Penampilan suatu tanaman merupakan hasil interaksi antara faktor genetik dan lingkungan, Faktor genetik berkaitan dengan pewarisan sifat tanaman, sedangkan faktor lingkungan berkaitan dengan kondisi lingkungan di tempat tanaman tersebut tumbuh (Gardner et al., 2008).

Berdasarkan penampilan morfologisnya, keragaman yang nyata dijumpai pada hampir seluruh sifat yang diamati, kecuali jumlah anakan produktif dan panjang malai berbeda dengan hasil analisis yang dilakukan hingga tanaman berumur $50 \mathrm{hst}$, pada keenam galur yang diuji, hampir semua variabel yang diamati menunjukkan perbedaan yang tidak nyata, kecuali akumulasi bahan kering.

Hasil penelitian menunjukkan adanya hubungan antara akumulasi bahan kering dengan hasil tanaman khususnya dilihat dari bobot gabah/rumpun. Berdasarkan hasil karakteristik agronomis pada periode umur tanaman 36-43 hst, galur UBPR6 memberikan hasil tertinggi dibandingkan dengan galur lainnya. Demikian pula dengan hasil tanaman UBPR6 memberikan hasil gabah tertinggi, yakni 82,50 g/rumpun (Tabel 6).
Tabel 6. Rata-rata Komponen Hasil dan Hasil Enam Galur Padi Rawa

\begin{tabular}{|c|c|c|c|c|c|c|c|c|}
\hline Galur & TT & JAP & $\mathrm{UB}$ & UP & PM & JBPM & PBB & BGPR \\
\hline UBPR2 & $110,33 \mathrm{~d}$ & 28,75 & $76.33 \mathrm{e}$ & $111.00 \mathrm{e}$ & 25,87 & $159.00 \mathrm{bc}$ & $85.49 \mathrm{ab}$ & $37.10 \mathrm{c}$ \\
\hline UBPR 3 & $94,66 \mathrm{e}$ & 31,33 & $96.33 \mathrm{~b}$ & $122.33 \mathrm{~b}$ & 29,74 & $0.33 \mathbf{a}$ & $70.44 \mathrm{e}$ & $34.30 \mathrm{c}$ \\
\hline UBPR6 & $125,75 \mathrm{bc}$ & 30,33 & $77.33 \mathrm{de}$ & $114.00 \mathrm{bc}$ & 26,94 & $212.20 \mathrm{a}$ & $95.03 \mathbf{a}$ & $82.50 \mathbf{a}$ \\
\hline UBPR7 & $113,27 \mathrm{~cd}$ & 25,58 & $85.33 \mathrm{ed}$ & $115.00 \mathrm{bc}$ & 25,74 & $182.13 \mathrm{~b}$ & $87.85 \mathbf{a b}$ & $68.93 \mathrm{ab}$ \\
\hline UBPR9 & $132,64 \mathrm{~b}$ & 30,16 & $92.66 \mathrm{bc}$ & $125.00 \mathrm{~b}$ & 27,35 & $143.2 \mathrm{~cd}$ & $78.12 \mathrm{bc}$ & $26.88 \mathrm{c}$ \\
\hline UBPR10 & $160,72 \mathrm{a}$ & 32,75 & $113.33 \mathbf{a}$ & $137.66 \mathrm{a}$ & 25,87 & $124.43 \mathrm{~d}$ & $78.26 \mathrm{bc}$ & $58.47 \mathrm{~b}$ \\
\hline LSD 0,05 & 14,69 & 7,5 & 8,77 & 11 & 3,42 & 27,91 & 12.09 & 20,6 \\
\hline
\end{tabular}

Keterangan : $\mathrm{TT}=$ tinggi tanaman $(\mathrm{cm}) ; \mathrm{UB}=$ umur berbunga (hst); UP=umur panen (hst) ; JBPM=jumlah gabah /malai (bulir); $\mathrm{PBB}=$ persentase gabah bernas; $\mathrm{BGPR}=$ bobot gabah/rumpun $(\mathrm{g})$

\section{KESIMPULAN}

Galur-galur yang dievaluasi menunjukkan pola pertumbuhan yang serupa, namun memiliki sifat fisiologis yang berbeda, tampak pada kemampuan tanaman dalam mengakumulasi bahan kering pada umur 40 hst. UBPR6 memiliki kemampuan mengakumulasi bahan kering tertinggi $(24,34 \mathrm{~g})$. UBPR10 merupakan galur yang memiliki postur tanaman tertinggi $(160,72 \mathrm{~cm})$, UBPR2 merupakan galur dengan umur berbunga dan umur panen paling genjah (76,33 dan 111 hst), sedangkan UBPR6 jumlah gabah/malai tertinggi $(212,2)$, persentase gabah bernas tertinggi $(95,03 \%)$, dan hasil tanaman tertinggi (82,50 g/rumpun).

\section{DAFTAR PUSTAKA}

Alihamsyah \& Ar-Riza. (2004). Potensi dan teknologi pemanfaatan lahan rawa lebak untuk pertanian. Makalah utama. Workshop Nasional Pengembangan Lahan Rawa Lebak. Kerjasama Balai Penelitian Pertanian Lahan Rawa-Pemda Kabupaten Hulu Sungai. Dinas Pertanian Propinsi Kalimantan Selatan, Kandangan, 11-12 Oktober 2004.

BPS. (2015). Statistik Indonesia. Badan Statistik Indonesia.

Chozin, M., Pujiwati, H., Rustikawati \& Sumardi, (2016). Optimization of PCR Protocol and Primers Screening for Development of Rapid Marker Associated with Submergence Tolerance in Rice Genotypes International Seminar sustainable utilization of coastal resourcesin tropical zone, 19-20 October,2016, Bengkulu, Indonesia.

Chozin, M., Sumardi, Sudjamiko, S. \& Barchia, M.F. (2017). Genetic variability and traits association analysis on F2 generations for determination of 
selection criteria in Indonesian inland swamp rice breeding.

Gardner, F.P., Pearce, R.B. \& Mitchel, R.L. (2008). Physiology of crop plants. Diterjemahkan oleh Herawati Susilo dan Subiyanto (Fisiologi Tanaman Budidaya). UI-Press.

Gomez, K.A. \& Gomez, A.A. (1984). Statistical Procedures for Agricultural Research. John Wiley \& Sons., Singapore.

IRRI (International Rice Research Institute and International Board for Plant Genetic Resources). (1980). Descriptors for Rice (Oryza sativa L). The International Rice Research Institute P. O. Box 933, Manila, Philippines.

Pusdata. (2013). Buku Informasi Statistik Pekerjaan Umum 2013. Kementerian Pekerjaan Umum Sekretariat Jenderal Pusat Pengolahan Data
Sagiman, S. (2007). Pemanfaatan lahan gambut dengan perspektif pertanian berkelanjutan. Orasi Ilmiah Guru Besar Tetap Ilmu Kesuburan Tanah, Fakultas Pertanian, Universitas Tanjungpura.

Suriadikarta \& Sutriadi. (2007). Jenis-jenis lahan berpotensi untuk pengembangan pertanian di lahan rawa. Jurnal Litbang Pertanian, 26(3), 115-122.

Suwignyo, R., Agus, Zulvica, F. \& Hendryansyah, (2008). Adaptasi teknologi produksi padi di lahan rawa lebak: Upaya menghindari pengaruh negatif terendamnya tanaman padi melalui pengaturan aplikasi pupuk nitrogen. Seminar Nasional Padi, Sukamandi.

Yoshida, S. (1981). Fundamentals of Rice Crop Science. International Rice Research Institute. Los Banos, Philippines. 